\title{
„Nocny złodziej jabłek" - Henryk Bereza i nurt chłopski w prozie polskiej
}

Andrzej Skrendo 


\section{"Nocny złodziej jabłek" - Henryk Bereza i nurt chłopski w prozie polskiej}

Andrzej Skrendo

TEKSTY DRUGIE 2017, NR 6, S. 36-53

DOI: $10.18318 /$ td.2017.6.3

1.

W roku 1994 Andrzej Sosnowski napisał kilka słów o świeżo wtedy wydanej książce Henryka Berezy Pryncypia ${ }^{1}$. Używam wyrażenia „kilka słów”, bo na pierwszy rzut oka mamy do czynienia z notatką na marginesie, choć w istocie okazuje się ona czymś więcej. Dwuznaczny jest sam tytuł. Terra Bereza to może znaczyć „ziemia, osobny kraj o nazwie Henryk Bereza"; ale wolno też formułę tę rozumieć jako „teraz Bereza”. Możliwość pierwsza daje sens pochwalny, druga - prześmiewczy, a może nawet lekko szyderczy. Pierwsza, jak się zdaje, jest bliższa samemu Sosnowskiemu, drugą wypadałoby uznać za swego rodzaju cytat z mowy wrogów autora Pryncypiów. Albo może, co gorsza, nie tyle wrogów, ile przeważającej części uczestników i obserwatorów życia literackiego. „A teraz Bereza, no proszę, ciekawe..." - tak mowa ta mogłaby brzmieć w umiarkowanej i lekko rozwiniętej wersji.

1 A. Sosnowski Terra Bereza, „Akcent" 1994 nr 3-4, s. 234-235. 
Ironia zawarta w owym zdaniu jest mocniejsza niż się wydaje - trzeba bowiem pamiętać, czym są Pryncypia. I dlaczego ukazały się w roku $1993^{2}$. Najkrócej mówiąc, są manifestem Berezy. Zbierają kilka świeżych, programowych tekstów, których celem było ponowne przedstawienie jego doktryny estetycznej. Chodziło o to, żeby podkreślić ciągłość i tożsamość myślenia Berezy w nowych, zrodzonych po 1989 roku, czasach. Żeby sformułować (a raczej: uzupełnić i powtórzyć) program, do którego (zdaniem Berezy) mogłoby się właśnie teraz wielu przyłączyć. No i żeby zaprzeczyć, że literatura PRL-u to „czarna dziura", jak powtarzano wówczas za Tadeuszem Nyczkiem. Co ważne, Nyczek metaforę tę ukuł właśnie w kontekście aktywności krytycznoliterackiej Berezy (choć zbiorowym i anonimowym wysiłkiem niejako uogólniono ją na całą spuściznę PRL-u). Mówił m.in. „o dogorywaniu tego, zresztą martwego od zarania, pomysłu Berezy z tą całą nową literaturą"3. I jest to znaczące sformułowanie. Zwróćmy uwagę: deiktyczne zaimki „tego" i „ta” podkreślają - z jednej strony - że mamy do czynienia z koncepcją łatwą do zidentyfikowania i powszechnie znaną, z drugiej sygnalizują równie powszechne lekceważenie. Ktoś mógłby nawet powiedzieć, że przypominają odczynianie uroku...

Jak wskazuje podtytuł książki Berezy, jego nowym formułom krytycznym jednego z pewnością nie można było odmówić i rzeczywiście nie odmawiano: patosu. Podobnie uczynił Sosnowski. Uznał Pryncypia za „świadectwo zaskakująco wzniosłego anachronizmu". Ale i to zabrzmiało dwuznacznie. Za chwilę bowiem dodał: "Anachronizm ten może być ważnym sygnałem dla następnego wieku”. Sosnowski wyjaśnił, na czym polega ów „anachronizm”:

2 H. Bereza Pryncypia. O łasce literatury, Oficyna Literacka, Kraków 1993.

3 „Ale w ogóle chciałem zapytać, czy nie macie panowie, jeśli idzie o lata 80., poczucia pewnej pustki? Muszę przyznać, że gdy pada pytanie o tę dekadę, mam jakąś dziurę w pamięci. Całe to dziesięciolecie jawi mi się jako czarna dziura, w której niewiele było autentycznych wydarzeń literackich, którą trudno ująć całościowo, opisać w jakichkolwiek kategoriach... Jest to głównie - jak powiedział Jarzębski - wyciąganie wniosków z rzeczy wymyślonych wcześniej, wykończenie istniejących już projektów, dotyczy to zarówno debiutantów, jak i klasyków. Myślę, rzecz jasna, cały czas o prozie. Na przykład dogorywanie tego, zresztą martwego od zarania, pomysłu Berezy z tą całą nową literaturą. Ostatni spór, jaki przed laty został wywołany artykułem Jana Błońskiego na łamach "Literatury”, tylko potwierdził, że była to w gruncie rzeczy rozgrywka wewnątrzliteracka, nawet wewnątrzkrytyczna, taka gra krytycznych szklanych paciorków. Publicznie to praktycznie nie istniało, chyba mało kogo obchodziło", Czarna dziura lat osiemdziesiątych. O literaturze ostatniej dekady dyskutują: Jan Błoński, Tadeusz Nyczek, Jerzy Jarzębski, Marian Stala oraz - ze strony redakcji TP-Jerzy Pilch, "Tygodnik Powszechny” 1990 nr 13. 
na „jakiejkolwiek wierze w pisanie i czytanie”. Pryncypia są „pryncypialne i bezpodstawne, oschłe i żarliwe, skromne i bezceremonialne, niezwykle odważnie przekraczają granice i terytoria literatury wysokiej i niskiej, życia i twórczości, a nawet teologii i kosmologii”. „Dziwna książka”, rzecze Sosnowski. Jak i inne tomy Berezy, chciałoby się dodać - i potraktować antytetyczne wyliczenie Sosnowskiego za niezłą charakterystykę całego dorobku Berezy.

Zajmę się tylko jedną z jego „dziwnych książek” - Związami naturalny$m i^{4}$. Jest najlepsza i najbardziej znacząca. W latach 70. była naprawdę szeroko komentowana, wywołała długotrwałe dyskusje na temat „nurtu chłopskiego”, wprowadziła ten termin do historii literatury. Koncepcję „nurtu chłopskiego" oddzielam ponadto - wbrew Berezie - od kwestii „rewolucji artystycznej". Z dzisiejszej perspektywy ta druga przysłoniła pierwszą a szkoda.

Uważam ponadto, że namysł nad tym, czym był „nurt chłopski” warto podjąć także z powodów innych niż ściśle historycznoliterackie - i to właśnie dziś. Wielokrotnie ogłaszano koniec tego nurtu wynikający z wchłonięcia i rozpłynięcia się chłopstwa jako klasy społecznej w całości społeczeństwa albo ze śmierci tradycyjnej kultury chłopskiej po zderzeniu z kulturą popularną i multimedialną. Nie chcę wdawać się w szczegóły tego rodzaju diagnoz, a tym bardziej w rozważania terminologiczne (dotyczące pojęcia klasy, kategorii chłopstwa, mechanizmów unifikacji społecznej etc.). Trudno jednak oprzeć się wrażeniu, że zażegnany jakoby podział się odtwarza - albo że tylko wydawało się, że został zażegnany. A jeśli tak, to co z tego wynika dla literatury?

4 Miała dwa wydania, pierwsze w roku 1972, drugie - niemal dwa razy obszerniejsze - w roku 1978. Nim właśnie się posługuję: Zwiq̨zki naturalne. Szkice literackie, wydanie drugie, zmienione i rozszerzone, Warszawa 1978, dalej jako ZN z podaniem numeru strony. Niekiedy będę też szerzej przywoływał książkę Bieg rzeczy (Warszawa 1982), znajdują się tu bowiem szkice Dopowiedzenie drugie oraz Wyznania stanowiące komentarz do Zwiq̨zków... i dyskusji, jakie tom ten wywołał - dalej jako BR z podaniem numeru strony.

5 Całkiem niedawno, z okazji wydania swej nowej książki Niebotyki Marian Pilot stwierdził w wywiadzie dla "Odry" (Na cmentarzu można odetchnąć. Z Marianem Pilotem rozmawiają Maciej Kostrzewa i Maciej Libich, „Odra” 2017 nr 7-8, s. 48): „w odpowiedzi na zajadłe sarmatyzmy literatura chłopska znowu staje się modna, popularna. Zupełnie tak, jak popularna była w latach pięćdziesiątych, sześćdziesiątych". Trzeba przyznać, wszystko jest w tych dwóch zdaniach zastanawiające - a może nawet zadziwiające. Ale godne namysłu. Co stwierdzam z pewnym smutkiem, albowiem na namysł ten miejsca tu nie znajdę. Ale może choć uda się podsunąć kilka argumentów do przyszłej dyskusji. 
2.

Charakteryzując postać Berezy w roku 2003, Zygmunt Ziątek był surowy ${ }^{6}$. Za prawdę o Berezie uznał już na wstępie obraz, jaki wyklarował się w polemikach dokoła „rewolucji artystycznej”. Bereza okazuje się krytykiem, który „[p] róby nawiązania dyskusji, wytknięcia uproszczeń czy braku argumentacji odbierał jako atak na siebie i po prostu nie przyjmował do wiadomości, widząc w nich stek kłamstw, obelg, pomówień, przeinaczeń"7; zabezpieczył się przed oponentami za pomocą "paszkwili na polską opinię literacką, które w ogóle wykluczyły sens dyskusji i potrzebę przekonywania"8; przypisał innym „stadny kretynizm, wyrażający się anachronizmem oczekiwań wobec literatury, brakiem zrozumienia jej swoistości, nieumiejętnością dokonywania elementarnych rozróżnień”; „obrażał wszystkich"9. Tyle Ziątek, a my dodajmy, że może to nawet więcej niż surowość... Nie chcę jednak spierać się o te oceny, tym bardziej że stoi za nimi interesujący i wnikliwy komentarz. Chciałbym natomiast zadać pytanie historyka literatury: kim był Bereza, gdy publikował Związki naturalne? Wydaje mi się, że warto spróbować na nie odpowiedzieć.

Otóż był autorem trzech książek krytycznych o tytułach: Sztuka czytania (1966), Doświadczenia: z lektur prozy obcej (1967), Prozaiczne początki (1971). Pierwsza z nich ukazała się na czterdzieste urodziny Berezy, można więc powiedzieć, że autor nie spieszył się z jej wydaniem (debiutował w 10. numerze „Twórczości” z roku 1952). Została zauważona, a jej rola polegała przede wszystkim na utwierdzeniu dobrej opinii o Berezie panującej w ówczesnym życiu literackim. Obszerną recenzję - zatytułowaną Sztuka bezinteresownej lektury - poświęcił jej Krzysztof Mętrak. Twierdził, że chodzi o „maksymalną bezinteresowność"10. Konstatował, że Bereza jest „konserwatystą krytycznym: godzi się na istniejący stan rzeczy i usprawiedliwia go”, ,literaturę traktuje jako świat statyczny i bezkonfliktowy, pozbawiony sprzeczności antagonistycznych”, wykazuje "pewien kontemplatywizm satysfakcji estetyczno-moralnych”. Dostrzegał „defensywność krytyki Berezy”, „bezbronność”

6 Z. Ziątek Misja odnowienia polskiej prozy (O krytyce Henryka Berezy), w: Sporne postaci polskiej literatury współczesnej. Krytycy, red. A. Brodzka-Wald, T. Żukowski, Warszawa 2003. Jest to znaczące, bo spierał się z Berezą o nurt chłopski jeszcze w latach 70., ogłaszając szereg znakomitych artykułów (utrzymanych w rzeczowym i pochlebnym, choć zwykle polemicznym tonie).

7 Tamże, s. 289.

8 Tamże, s. 289-290.

9 Tamże, s. 290.

K. Mętrak, Sztuka bezinteresownej lektury, „Twórczość” 1967 nr 4, s. 103. 
oraz „nieśmiałość”. Powodem miał być „liberalizm duchowy krytyka”" „Każdy z nas jest trochę Berezą wobec literatury, a to wtedy, gdy znajduje w niej ukojenie duchowe", stwierdzał'12. Zarazem jednak nie miał wątpliwości w kwestii najważniejszej: „Język krytyczny Berezy jest natychmiast rozpoznawalny"13.

Recenzując Doświadczenia..., Jan Pieszczachowicz w tekście Za co kochać literaturę za rzecz kluczową uznał fakt, że Bereza postępuje zawsze „z dużym taktem i znawstwem”. Utrzymywał, że według Berezy w krytyce „nie ma miejsca na «zapładniaczy» literatury, gdyż byłoby to oczywistą uzurpacją jej autonomii"14. Dostrzegał, że za każdym razem, gdy przychodzi Berezie zaprzeczyć uznanym hierarchiom, czuje się on wielce onieśmielony, a nawet pojawia się u niego "coś na kształt zażenowania"15.

Czy są to reprezentatywne wyimki z tekstów Mętraka i Pieszczachowicza? Zapewniam, że tak. Czy mylili się oni poważnie w swych diagnozach? Wniosek taki byłby, jak mniemam, zbyt łatwy. Zresztą, każdy z nich powołuje się na to, co o Berezie „się wie”. Czy ich opinie były odosobnione? W żadnym razie - co pokazuje znakomity odbiór kolejnej książki Berezy, Prozaicznych początków. Zobaczmy.

Lothar Herbst zauważa, że Bereza „rzadko się myli”, choć zakres jego lektur jest „bardzo szeroki”16. Halina Zaworska stwierdza, że „nikt chyba nie orientuje się tak dokładnie w całości młodej prozy"17 jak Bereza. Ryszard Matuszewski, zgadzając się, że w tej kwestii "nikt mu nie dorówna”, dodaje, że stworzył Bereza osobny, swoisty „ascetyczny kanon stylu pracy krytycznej”, jego zaś wybory i oceny są „wyznacznikiem literackiej rangi”"18. Henryk Krzeczkowski twierdzi, że to, co pisze Bereza, ,jest zawsze pilnie czytane, zwłaszcza przez pisarzy”, i prorokuje, że jego nowa książka wywoła „bardziej

Tamże, s. 104.

Tamże, s. 105.

Tamże, s. 106.

J. Pieszczachowicz Za co kochać literaturę, "Miesięcznik Literacki” 1968 nr 6, s. 124.

Tamże, s. 125.

L. Herbst Młoda proza pod krytycznym obstrzałem, „Nadodrze” 1972 nr 3, s. 9.

H. Zaworska Grzesznych obcowanie, „Odra” 1972 nr 1, s. 98.

R. Matuszewski O szkicach Henryka Berezy i kanonie moralnym krytyka, „Współczesność” 1971 nr 26, s. 3 . 
niż to dotąd bywało ożywione rozmowy w środowisku literackim"19. Zbigniew Bieńkowski z entuzjazmem zaczyna swą obszerną recenzję od tego, że Bereza jest „jedynym”, który uprawia „krytykę czystą"20. Wyznaje, że „podziwiał wielokrotnie wrażliwość i dociekliwość"21 Berezy. Mętrak zwierza się, że zna wielu autorów, „niegłupich” - jak dodaje, którzy „mówią o sobie wyłącznie słowami wyjętymi z omówień Berezy”22. Pisarze „mogą [więc] czuć się zaszczyceni jego wyborem"23 - samym faktem, że o nich pisał. Wacław Sadkowski odnotowuje, że Bereza to krytyk wybitnie „«umuzykalniony», wrażliwy na każdy oryginalnie brzmiący ton w kakofonicznym niemal chaosie prób i poszukiwań", całkowicie „wolny od koteryjnych zacietrzewień, animozji i uprzedzeń" ${ }^{24}$. Wreszcie Tadeusz Nyczek. Narzeka on wprawdzie, że Bereza jest zbyt dobrotliwy, w wyniku czego pozostawia za dużo „miału zmieszanego z wartościowym kruszcem”, zarazem jednak dzieli się bardzo znaczącym zwierzeniem: „Gdybym przeczytał wszystkie książki, o których pisze [Bereza] w Prozaicznych początkach (a na pewno od czasu skompletowania tych szkiców przeczytał drugie tyle), następnie zaś tajemnym sposobem zmienił się w Berezę, kazałbym własnym przyszłym recenzentom wykazać się wpierw co najmniej podobnym wynikiem. Ponieważ jednak, jak sądzę, nie znalazłby się poważny konkurent, ja nie będę Berezą, a Prozaiczne początki, niezależnie od tego, trzeba przecież omówić. Mam nadzieję, że autor ich nie weźmie mi za złe niekompetencji; dalibóg wielu z tych dzieł nie znam..."25.

Być może było to przydługie wyliczenie. Zapewne nieco nużące. Chyba wynikają z niego banalne wnioski. Ale mimo to spróbujmy je wysłowić. Po pierwsze, ukazuje ono jakby zapomnianą twarz Berezy i powody jego (niegdysiejszej) zasłużonej sławy. Po drugie, ujawnia sytuację, w jakiej ukazały się Zwiazki naturalne: daje pewne pojęcie o oczekiwaniach i reakcjach czytelniczych. Po trzecie, przestrzega przed uproszczeniami i skrótami perspektywy w ocenie pisarstwa autora Pryncypiów.

\footnotetext{
H. Krzeczkowski Spór o kryteria, "Tygodnik Powszechny” 1971 nr 43, s. 6.

Z. Bieńkowski Krytyka czystego serca, „Twórczość” 1972 nr 1, s. 105.

Tamże, s. 107.

K. Mętrak Krytyka jako partnerstwo, „Kultura” 1971 nr 4, s. 9.

B. Kazimierczak Prozaiczne poczq̨tki, "Kierunki” 1972 nr 3, s. 9.

W. Sadkowski Patron i mecenas, "Nowe Książki” 1972 nr 5, s. 29.

T. Nyczek Szkoła czytania, „Miesięcznik Literacki” 1972 nr 4, s. 122.
} 
3.

Perspektywa, jaką rysuje Bereza w Zwiazkach naturalnych, jest szeroka. Kultura polska - przypomina krytyk - była przez wieki kulturą inteligencką, rozwijała się w oderwaniu od chłopskich źródeł. A przecież chłopi stanowili zawsze zdecydowaną większość ludności kraju. „Polska kultura chłopska utrzymywała się na prawach rezerwatu sił kulturotwórczych w stanie niemal odwiecznej pierwotności” - „jak nigdzie na świecie” (ZN 10). Nurt chłopski istniał wprawdzie w renesansie, ale rychło zanikł - teraz rodzi się na nowo. Na naszych oczach dokonuje się osobliwe powtórzenie (w takim sensie, w jakim - powiedzmy umownie - Žižek każe powtarzać Lenina) przewrotu renesansowego. Perspektywa zarysowana w Związkach naturalnych sięga więc tego, co było „przed wiekami” (ZN 9), a może nawet i dalej - gra idzie o „odzyskanie tysiącletnich zasobów chłopskiej kultury” (BR 26$)^{26}$.

Czym okazują się te „zasoby”? „Niezależnie od wszystkich różnic pewne wspólne rysy są jednak rozpoznawalne. Przejawiają się one w zbieżności pewnych doświadczeń społecznych, egzystencjalnych i kulturalnych, w inklinacjach myślowych i estetycznych, w predyspozycjach wyobraźni, w stosunku do języka, w rodzaju wrażliwości moralnej" (ZN 12). Są to, powtórzmy, „najstarsze i najtrwalsze historycznie społeczne źródła kultury” (BR 30), "wyzwolone siły kulturotwórcze”, które mają "wiele do zdobycia, a jeszcze więcej do dania” (ZN 10). Występują one przeciw polszczyźnie, która „konwencjonalizowała się w stopniu nie spotykanym w innych literaturach" (ZN 9), wytwarzała „aprioryczne hierarchie wartości literackich” (ZN 29), tworzyła „urojenia kulturalne" (BR 25).

Uogólniony opis zarysowanej sytuacji przedstawia się następująco: „Społeczeństwo polskie znalazło się w tyglu kulturalnym, w którym pod zwiększonym ciśnieniem wytapia się coś, o czym nie wiemy, co to może być” (ZN 15). Wolno też powiedzieć, że dochodzi do „zderzenia kultur” (ZN 10). Albo że

W sensie socjologicznym i historycznym są to tezy szeroko znane, zob. np. I. Ihnatowicz, A. Mączak, B. Zientara, J. Żarnowski Społeczeństwo polskie od X do XX wieku, wyd. 3, Warszawa 1996, s. 468: „U schyłku Rzeczypospolitej przedrozbiorowej było na ziemiach etnograficznie polskich około 1400 miast, jednak nie więcej niż 10\% z nich mogło naprawdę uchodzić za miasta, a miast przekraczających zawrotną na owe warunki liczbę 10000 mieszkańców było zaledwie kilka". We Francji mieszkało wtedy w miastach ponad 20\%, a w Anglii ponad 30\% mieszkańców. Zob. też: Zarys historii Polski, red. J. Tazbir, Warszawa 1979, s. 397, gdzie czytamy, że w roku 1815 aż „blisko $80 \%$ ludności Królestwa Polskiego utrzymywało się z rolnictwa, lecz 800 tys., to znaczy blisko 30\% ogółu ludności wiejskiej, stanowili bezrolni chłopi. W grupie 70\% chłopów posiadających ziemię chłopi pańszczyźniani stanowili 48,5\%, czynszownicy 16,5\%, koloniści 5\%". W Galicji chłopi stanowili ponad 85\% ludności. 
„[z]acofanie literackie - podobnie jak zacofanie społeczne - sprzyja wybuchom rewolucji" (ZN 30). Wszystko to jednak z bardzo ważnym zastrzeżeniem: ci, którzy wyrażają pragnienie „rewaluacji kultury chłopskiej, chcieliby ją rewaluować nie jako całość, lecz jako źródło staro-nowych wartości kulturalnych" (ZN 15). Zastrzeżenie to nie jest zupełnie jasne, sam Bereza skłonny był je rozumieć na kilka sposobów, niemniej odgrywa kluczową rolę: czym zatem są owe „staro-nowe wartości”?

Zacznijmy od tego, że koncepcja nurtu chłopskiego uwikłana jest w kilka sprzeczności albo też - mówiąc inaczej - zmusza Berezę do podtrzymywania opozycyjnych dążeń. Można je oceniać negatywnie, można uznać za siłę napędową i przyczynę atrakcyjności. Po pierwsze, determinizm versus woluntaryzm. Tak tę opozycję przedstawia sam Bereza: „Literatura dzisiejsza, która więcej wyraża człowieczeństwo, niż w taki czy inny sposób objaśnia, opowiada się raczej za różnymi formami determinizmu twórczego, a w każdym razie wyklucza zupełny woluntaryzm” (ZN 7). „Objaśnianie” wiedzie do myślenia w kategoriach "tematu wiejskiego" i kojarzy się Berezie z tradycją paternalizmu kulturowego, ,kultem podrabianych świątków” (ZN 112) - dominującym w całej polskiej tradycji literackiej. „Wyrażanie” wiąże krytyk ze społeczną genealogią pisarzy, która decyduje o tożsamości nurtu chłopskiego - i dlatego właśnie mowa o "nurcie”, a nie o „temacie”. Łatwo dostrzec, że pierwsza kategoria wydaje się za wąska, druga za szeroka - i trudno je pogodzić. Andrzej Zawada utrzymywał, że Bereza mimo to stosuje obie naraz, są one bowiem "narzędziami wstępnie wyznaczającymi zakres badanego zjawiska, a nie sprawdzianami ostatecznymi"27. Ale zdaje się, że Bereza myślał jeszcze inaczej, w sposób - by tak rzec - nieprzechodni: temat wymaga genealogii, lecz genealogia nie określa tematu (jak u Przybosia na przykład). Albo: trzeba dopuścić myśl, że genealogia bywa w kulturze kwestią wyboru, a nie tylko urodzenia. Dziedzictwo można wybrać - mimo że zwykle otrzymuje się je w spadku. Albo: genealogia jest ważna, bo literatura rodzi się w świecie podziałów społecznych (nawet jeśli jej punktem docelowym jest uniwersalizm, który pozostaje z definicji ahistoryczny). W związku z tym należy przyjąć punkt widzenia "społecznej historii literatury” (ZN 8) - i tak też Bereza czyni. Jednak napięcie między „determinizmem" a „woluntaryzmem",

27 A. Zawada Co wiemy, czego nie wiemy (nurt ludowy w oczach współczesnej krytyki), "Regiony” 1976 nr 4, s. 6o. Szkic ten wszedł do ważnej książki Zawady Gra w ludowe. Nurt chłopski w prozie współczesnej a kultura ludowa, Warszawa 1983. Zauważmy wahanie Zawady między "nurtem ludowym” a „nurtem chłopskim”. 
ujęciem „podmiotowym" a "przedmiotowym" (jak mówiono w dyskusjach wokół koncepcji Berezy), nurtem a tematem - pozostaje nieredukowalne ${ }^{28}$.

Po drugie, partykularyzm versus uniwersalność. Stare, nowe czy „staro-nowe"? Zmiana tego, co jest; wprowadzenie nowego; czy ani jedno, ani drugie, tylko coś innego? Nurt chłopski w literaturze - czy nowa literatura? Jak wiadomo, ostatecznie Bereza orzekł, że nowa literatura - i jest w tym jakaś konsekwencja. Z nurtu chłopskiego wywiódł „rewolucję artystyczną”. Ale w Związkach naturalnych kwestia ta jeszcze się nie rozstrzygnęła. Z jednej strony nalega Bereza na partykularyzm: im większa przepaść między kulturą chłopską a oficjalną, zwłaszcza jeśli nazwiemy ją (w sposób genealogiczny) szlachecko-inteligencką, tym wyraziściej przedstawia się nowy nurt i tym większą uzyskuje wartość. To wymóg taktyczny. Ale jest i strategiczny: emancypacja musi mieć wprawdzie napęd dla swej ekspansji, lecz wraz z własnym postępem nieuchronnie go traci, albowiem jej celem jest likwidacja stanu, który ją wyzwolił. Jak to pogodzić? Bereza podejmuje tę alternatywę z otwartą przyłbicą. Potwierdza, że kultura chłopska obecnie ,jest całkowicie anachroniczna jako zjawisko, jego likwidacja jest koniecznością historyczną" (ZN 10).

28 Zbigniew Ziątek pisał (Powtórki z historii sporów „ Regiony” $1975 \mathrm{nr}$ 4, S. 53): „Nie słychać [...] by sprawa rozgraniczenia literatury o wsi i literatury samej wsi stanęła gdzieś równie ostro jak u nas". Gdzie indziej (Tematyka wiejska w prozie współczesnej, w: Literatura a współczesne przemiany społeczne. Sondaże, red. A. Brodzka i M. Żmigrodzka, Warszawa 1972, s. 73) tłumaczył, że chłopskie pochodzenie jako objaśnienie tożsamości nurtu, i samo pojęcie nurtu, nie odpowiada na pytanie, dlaczego pisarze podejmują "literackie powroty na wieś" (które są przecież kwestią wyboru, a nie przymusu), co prowadzi do „fetyszyzacji podmiotowego kryterium społecznego, do przeceniania faktu, że twórcy tego nurtu są z pochodzenia chłopami”. I dalej: „Pojęcie nurtu byłoby bardziej prawomocne, gdyby nie ograniczało się do pisarzy pozwalających się wyodrębnić przy pomocy kryterium tematycznego albo gdyby je uzupełnić wiedzą o historycznych determinantach zmieniających się ujęć tematyki wiejskiej, obszarze określającym podejmowanie pisarskich decyzji" (tamże, s. 75). Oczywiście, w zakresie szeroko pojętej socjologii literatury, nie da się sformułować tego rodzaju „wiedzy”, choć - jak się zdaje - jakąś spekulatywną "teorię" na ten temat dałoby się chyba wydobyć z prac Berezy. Miałaby ona charakter freudowsko-marksowski. Po dwudziestu latach, w roku 1992, Ziątek podsumowywał (hasło: Ludowe czasopisma - programy literackie, w: Słownik literatury polskiejXXwieku, red. A. Brodzka, M. Puchalska, M. Semczuk, A. Sobolewska, E. Szary-Matywiecka, Wrocław-Warszawa 1992, s. 612): „Modyfikacje koncepcji Berezy przez najbardziej zainteresowanych, jak i polemiki z tymi koncepcjami, znalazły cząstkowy tylko wyraz na łamach «Tygodnika Kulturalnego». Polemiki były mało skuteczne, ponieważ najczęściej miały charakter sporów terminologicznych oraz konkurencyjnych ujęć dorobku pisarzy pochodzenia chłopskiego, a także dlatego, że w latach siedemdziesiątych nastąpił proces cofania się różnych orientacji pisarskich do własnych «korzeni» i ta propozycja samookreślenia się, jaką przedstawił Bereza, była najbliższa potrzebie zachowania własnej tożsamości pisarzy". 
Nurt chłopski „będzie musiał zaginąć” (ZN 11).W szkicu o dorobku Stanisława Czernika Bereza pisze, że autor ten skonstruował „swój mit chłopskiego rodowodu od czasów prasłowiańszczyzny" (ZN 54), ale całkowicie zdawał sobie sprawę z „mitotwórczego charakteru swoich poszukiwań”. „Czysty rodowód chłopski jest w Polsce tak samo mało prawdopodobny jak czysty rodowód szlachecki" (ZN 54), twierdzi Bereza. Nie tylko zatem zaciera przepaść między kulturą chłopską a oficjalną, ale także podkreśla wewnętrzne zróżnicowanie tej pierwszej. Podobne dążności znajdziemy w szkicu o Nowaku. Bereza wynosi Nowaka bardzo wysoko, ale to tylko jedna strona sprawy - „Doskonała jedność tego świata” (ZN 197). Druga to fakt, że Nowak „otarł się o koniec raju chłopskości, ale udał, że tego nie zauważa" (ZN 204). Berezę zatem najbardziej fascynuje nie tyle sama wielkość sztuki Nowaka, ile jego „heroiczna” walka z „nieuchronnością konwencjonalizacji” (ZN 201). Uporczywe pragnienie, aby „istnieć w bezczasie” (ZN 204; powołuje się Bereza m.in. na ciekawe opowiadanie Mojżesz, które nawet Holocaust przemienia w mit). Szkic, co wydaje się znaczące, kończy się konstatacją porażki: powieść Dwunastu „po raz pierwszy u Nowaka tworzy wrażenie sztuczności” (ZN 214). „W tej [całej chłopskiej] literaturze potrzebne jest, a nawet konieczne pożegnanie z mitem" (ZN 128). To z kolei przy okazji twórczości Kawalca...

Podsumujmy: z punktu widzenia zajętego w Związkach naturalnych późniejsza idea rewolucji artystycznej okazuje się krokiem wstecz - choć wydaje się krokiem do przodu. Utwardza opozycję między partykularyzmem a uniwersalnością, żywi się jej wzmacnianiem. Zamiast opowiadać o konieczności utraty początku, skupia się na nadziei jego odzyskania ${ }^{29}$.

Po trzecie, mowa versus pismo ${ }^{30}$. Za właściwą i jedyną tradycję prozy chłopskiej - miała ona do tej pory tylko „dziewiętnastowieczną tradycję

29 Zwykle jednak sądzi się co innego. Dobre o tym pojęcie daje Jan Galant (Polska proza lingwistyczna. Debiuty lat siedemdziesiątych, Poznań 1998, s. 33) piszący: „skrajnie estetyzujący, antymimetyczny i mitograficzny program [Berezy] doskonale przystawał do powieści powstałych w obrębie nurtu wiejskiego w prozie polskiej". Prawodawcą tego osądu jest Jan Błoński z niegdyś głośnego pamfletu Dwie groteski - i pół ("Literatura" 1987 nr 5), zapoczątkowującego dyskusję na temat "rewolucji artystycznej”. Proza "przewrotnie artystowska”, "wybitnie estetyczna, wyzbyta ambicji mimetycznych czy poznawczych" (s. 14), "literackość tego żywiołu" (s. 15), oto określenia wprowadzone przez Błońskiego. Ostatecznym potępieniem okazała się fraza "wszystko istnieje na równych prawach" (s. 15), za pomocą której Błoński odprawiał zresztą wielu innych, na przykład Różewicza.

30 Pod koniec życia, w roku 2010, objaśniając swą koncepcję literatury, Bereza powie (A. Wiedemann, P. Czerniawski Końcówki. Henryk Bereza mówi, Kraków 2010, s. 133-135): „Podstawowe jest oczywiście rozróżnienie między językiem pisanym i językiem mówionym. Cała moja 
zastępczą" (ZN 17), polegającą na „literackim handlu chłopską rodzajowością, albo na nauczaniu maluczkich" (ZN 82) - uznaje Bereza Listy emigrantów z Brazylii i Stanów Zjednoczonych 189o-189131. Szkic o tym tomie uzyskuje znaczący tytuł Odzyskane źródła. W listach chłopskich półanalfabetów znajduje Bereza dostęp do "nie eksploatowanych przez wieki żywych źródeł literackiego języka”, wykwit „wielowiekowego szlifunku” (ZN 25), świadectwo całkowitej niezależności „od konwencji piśmienniczych” (ZN 20) i „piśmiennych zniekształceń" (ZN 21). Natychmiast kojarzy owe listy z awangardowymi eksperymentami Białoszewskiego i Buczkowskiego (zob. ZN 23) ${ }^{32}$, broniąc je przed zarzutem prymitywizmu. Ale czego te listy w istocie dowodzą, oprócz faktu, że raz utraconą prostotę można odzyskać dopiero u szczytu wyrafinowania? Jak pisze w przedmowie Witold Kula, kłopot polega już na tym, że „[t]radycyjna cywilizacja wiejska, podobnie jak i plebejsko-miejska, nie zna listu. Chłopak, który wyszedł ze wsi szukać szczęścia, gdzie oczy poniosą, umierał jakby dla swej rodziny i dla społeczności wiejskiej"33. Obecność litery (zgodnie z klasycznymi ustaleniami Derridy) rozszczepia źródło. Samo istnienie listu jest zniekształceniem czystości mowy: zarówno w sensie historycznym (jak wynika z uwagi Kuli), jak i „metafizycznym”. Zresztą, skądinąd Bereza o tym świetnie wie. W rozdziale o Ożogu zwierza się ze swego marzenia: „Marzy mi się od dawna pisarz, który by widział i czuł prawdziwie ludzi polskiej wsi, który by miał ucho dla filozoficzności tego języka" (ZN 115). Ale do razu

koncepcja literacka polega na tym, że rozwój literatury jako zjawiska charakteryzującego epoki i całe procesy nie może być oderwany od języka mówionego, od mowy, że język mówiony, mowa jest podstawową postacią języka, język pisany jest już formą okaleczoną i normy języka pisanego nie mogą być normami aktywności twórczej, ponieważ autentyczne, pełne życie językowe realizuje się w mowie i tylko w kalekiej postaci może realizować się w języku pisanym. To jest fundament mojego rozumienia literatury". Ale niestety - mimo tytułu tego tomu i mimo naśladowania mowy w tym zapisie (i w całości tomu), mamy oczywiście do czynienia tylko z naśladowaniem. Być może zatem dzieje się raczej tak, że literatura nigdy nie staje się kaleka, lecz zawsze taka się rodzi - i nigdy nie potrafi stać się tym, czym jest.

Listy emigrantów z Brazylii iStanówZjednoczonych 1890-1891, red. W. Kula, N. Assorodobraj-Kula, M. Kula, Warszawa 1973 (posługuję się wydaniem Warszawa 2012).

Tu zwróćmy uwagę na fragment Doświadczeń... (s. 92; jest to rozdział o Joysie): „Nie tak dawno zetknąłem się z tekstem o właściwościach samorodnego autentyku ludowego, w którym osobowość chłopską kreowano w syntetycznym (można powiedzieć Joyce'owskim) ujęciu czasu i przestrzeni. Autor tego tekstu nie mógł słyszeć nazwiska Joyce'a. [...] Bez nazwiska Joyce'a nie można się obyć przy rozważaniach o literaturze współczesnej, bezpośrednio z nim samym nie mającej nic wspólnego". 
zastrzega: „Nie chodzi mi, rzecz jasna, o naturalistyczny zapis gwarowy. To by nie miało najmniejszego sensu”, idzie jedynie o „literacką eksploatację języków środowiskowych" (ZN 115-116). Zgodnie z tym założeniem napomina więc Bereza Adolfa Momota, że „nic nie jest dziś mniej wiarygodne literacko jak prostota czy naiwność” (ZN 224). „Z samych inności (jakichkolwiek) nic jeszcze dla literatury nie wynika. Inne to nie znaczy jeszcze literacko dobre i literacko prawdziwe” (ZN 223). Odrzucenie „konwencjonalnych prawideł języka”, ,zamach na gramatyczno-logiczną strukturę pisanego języka” trzeba „każdorazowo uzasadnić”. Niekiedy „błędy gramatyczne są tylko i wyłącznie błędami gramatycznymi" (ZN 228).

No tak, wszystko to może i ciekawe - mógłby ktoś powiedzieć - ale cokolwiek oczywiste, a poza tym jak się ma do tego, co Bereza pisał na temat Listów emigrantów...? Wróćmy do szkiców o Białoszewskim i Buczkowskim. Istota przedsięwzięcia tego drugiego polega, jak twierdzi Bereza, na chęci „dobrania się do rzeczywistości, żeby tak rzec, samej w sobie” (ZN 16o). W Urodzie na czasie prowadzi to do powstania tekstu, który „z powieścią nie ma już nic wspólnego” (ZN 162). „Czy nie zorganizowano jej [tej domniemanej powieści] w ogóle?” i czy „usprawiedliwione byłoby odmówienie tekstowi Buczkowskiego wartości literackiej?" (ZN 163) - pyta otwarcie Bereza (a pytania te brzmią bardzo szczerze). Nie, bo mamy do czynienia ze „zbiorem kilku tysięcy najpiękniejszych zdań, jakie w polszczyźnie mówionej dadzą się sformułować” (ZN 163), choć ostatecznie Uroda na czasie to jedynie „ciąg językowych prowokacji” (ZN 165). Z kolei w prozie Białoszewskiego są „wyczuwalne pogłosy bełkotu”, ale nie dochodzi nigdy do „żadnej autonomicznej jego prezentacji", zgodnie z zasadą "dopuszcza się narracyjną swobodę, ale nie dopuszcza dowolności” (ZN 190). Mimo to Bereza twierdzi, że Białoszewski pisze „pod dyktatem rzeczywistości, czyli życia, czyli żywej mowy”.,Dyktatowi przeciwstawia się podmiotowe prawo wyboru, podmiotowa chęć zapisywania, podmiotowy sposób zapisu, są to jednak podmiotowości nieistotne, skoro przyjmuje się warunki dyktatu, skoro od materii dyktatu nie można odstąpić, skoro dyktat reprezentuje podmiotowość nadrzędna, wobec której obowiązuje bezwzględny respekt, jeśli tylko podejmie się decyzje zapisu" (ZN 191).

Co wynika z doświadczeń Berezy z Buczkowskim i Białoszewskim? Jak się zdaje, Bereza przedstawia zjawisko, które można by nazwać likwidacją pośrednika w jego wytworze. Ukazuje dwóch wymienionych pisarzy jako autorów, którzy występują przeciw znakowej naturze języka. Z dzisiejszej perspektywy nic nadzwyczajnego, niegdyś jednak - w latach 6o. i 70. - interpretacje 
takie były paralelne wobec dążności najnowszej francuskiej teorii literatury. Ale to spostrzegł Bereza dopiero w dziesiątej dekadzie, czego dowodem Wypiski $^{34}$ - ale niestety odkrycia tego (z powodu swego słabego przygotowania filozoficznego, a także żywionej przez lata otwartej pogardy wobec literaturoznawstwa) nie potrafił zdyskontować. Pozostaje jeszcze być może najbardziej kłopotliwy fakt - że inwazja mowy żywej jakby nieuchronnie wyraża się w tekstach, które narażone są na zarzut bycia stylizacją lub w każdej chwili mogą o stylizacyjność być posądzone. Jest to z pewnością kłopot istotny z punktu widzenia programu rewolucji artystycznej, której celem było wprowadzenie nowego na miejsce starego. Nurt chłopski może jednak poprzestać na tym, co „staro-nowe”. Na zachęcie do równouprawnienia różnych języków artystycznej ekspresji.

\section{4 .}

Recenzując Związki naturalne, Ziątek nazwał je „najważniejszą książką Henryka Berezy” oraz „jedną z najważniejszych książek krytycznych okresu powojennego" ${ }^{35}$. Roch Sulima uznał je w swej recenzji, a raczej rozprawie napisanej na marginesie tomu Berezy, za „próbę powołania nowego języka”36. Leszek Bugajski wyraził przypuszczenie, że Bereza ,zajął się tak blisko nurtem chłopskim nie dlatego, że zafascynowany był kulturą chłopską i jej literackim awansem, nie dlatego, że fascynowały go przemiany zachodzące w kulturze ludowej i ich literacki odprysk, ale dlatego, że odkrył u tych pisarzy możliwości językowego nowatorstwa" ${ }^{37}$. Odkrył w kulturze chłopskiej, dodajmy, cechy przeciwstawne do tych, jakie jej zwykle przypisywano: „ahistoryzm, konserwatyzm oraz izolację", a w szczególności biernośćs ${ }^{38}$. Chłopi ostatecznie stali się dla Berezy tym, czym proletariat dla Marksa: nadzieją rewolucji. Ultranowoczesny przewrót ma być dokonany przez klasę najbardziej zacofaną.

34 H. Bereza ...wypiski..., wypiski z lat 1991-2004 w wyborze P. Nowakowskiego i A. Skrendy, posłowie A. Skrendo, Szczecin 2006.

Z. Ziątek Filozofia "Zwiq̨zków naturalnych", "Tygodnik Kulturalny" 1979 nr 13, s. 3.

R. Sulima Krytyka heroiczna, „Regiony” 1979 nr 1, s. 63.

L. Bugajski Potrzeba obcowania z prawdq , "Kultura” 1979 nr 36, s. 4.

38 Jak stwierdza Bronisław Gołębiowski w szkicu W poszukiwaniu bohatera chłopskiego, zawartym w tomie Literatura a współczesne przemiany..., s. 10. 
Zarzucano Berezie, że tożsamość nurtu chłopskiego zbudował na „spekulacji na temat genealogii społecznej pisarza, jego związku z zapleczem macierzystej kultury i jego stosunku do kultury oficjalnej, na temat rewaluowania i obumierania tradycji kulturalnych" oraz oparł na „nieweryfikowalnym założeniu, że zjawisko na terenie prozy [...] można i należy wyjaśniać [...] na płaszczyźnie poza- czy ponad-, czy okołoliterackiej"39. Co gorsza, „wyeksponowanie momentu genealogicznego [...] ułatwiało utożsamianie dorobku twórczego pisarzy chłopskiego pochodzenia z dorobkiem polityki kulturalnej Polski Ludowej. I to, niestety, przez obydwie strony: rzeczników i - często - przeciwników tej polityki"40. Niektórzy dochodzą nawet do zarzutu, że ci, którzy pragnęli wyprowadzić kulturę chłopską z getta, sami się w nim zamknęli, a do tego było to getto politycznie koncesjonowane przez komunistyczne władze. W tej sprawie powiem tylko tyle: ma to znaczenie, o ile pamięta się, że miało kiedyś - przy czym kiedyś miało na pewno, a dziś zapewne już nie.

Ciekawe jest co innego: aby spojrzeć na Zwiąki naturalne jako ponowienie idei Ignacego Fika zarysowanych przed wojną w Rodowodzie społecznym literatury polskiej ${ }^{41}$. Tym bardziej, że Bereza sam używa wyrażenia „społeczny rodowód literatury" (ZN 70). Wymienię kilka fragmentów, które wypowiedział Fik, ale które brzmią jak wyjęte z ust Berezy. Uspołecznienie literatury wiedzie przez uspołecznienie twórcy - to wspólne założenie wstępne. Nadzieja dla literatury jest w tym, że „[u]świadomić sobie tendencje rozwojowe pewnych grup społecznych, z którymi autor jest z związany, zająć wobec nich pewne aktywne stanowisko, dać na zewnątrz szczery wyraz literacki oto warunek, który spełniając pisarz dla każdej swej manifestacji literackiej zdobywa wartość społeczną" (WPK 302). Literatura polska jest „warstwą bardzo cieniutką", przeto przez „dobre pięćset lat dzieje Polski nie stanowią

Z. Ziątek Literatura nowych doświadczeń społecznych, "Regiony” 1976 nr 4, S. 54.

Z. Ziątek Głód syntezy. Wiesław Myśliwski i proza chłopska, w: Sporne postaci polskiej literatury współczesnej. Następne pokolenie, red. A. Brodzkaj i L. Burska, Warszawa 1995, s. 152. Można jednak też znaleźć opinie usiłujące wyjść poza ten spór (S. Burkot Literatura polska 1939-2009, Warszawa 2010, s. 198): „Nurt chłopski w literaturze lat sześćdziesiątych [...] nie jest produktem bezpośrednim układu politycznego, w którym partia chłopska uchodziła za «współrządzącą». Pisarze tego nurtu nie tworzyli powieści politycznych, nie wyrażali bezpośrednio interesów ugrupowania, choć nie odżegnywali się od związków z chłopskim ruchem politycznym".

41 I. Fik Rodowód społeczny literatury polskiej, w: tegoż Wybór pism krytycznych, wyd. 2, oprac. i wstępem opatrzył A. Chruszczyński, Warszawa 1961; dalej jako WPK z podaniem numeru strony. 
odpowiedniego przykładu dla zilustrowania zajmujących nas tu rozważań" (WPK 322). Wreszcie jednak „[z]aczynają pisać autentyczni ludzie pracy, likwidując w ten sposób mieszczański pogląd na inteligencję jako odrębną i nadrzędną warstwę, przeznaczoną do wytwarzania wartości kulturalnych, będących do dyspozycji wyłącznie dla elity. Przed wojną [pierwszą światową] chłop piszący musiał albo zupełnie się zdeklasować, albo poprzestać na prymitywie, ustalonym zresztą przez mieszczańskich chłopomanów [...]. Było się albo tylko pisarzem, albo tylko chłopem” (WPK 420). „Chłop nie potrzebuje książek, które by rozmazywały jego niedole lub przedrzeźniały język. Chłop nie chce być zamknięty w rezerwacie, jak egzotyczne zwierze w zoologu" (WPK 486). Jego język, gwara, nie powinien być „imitowany, ale twórczo wykorzystany dla dobra całego języka polskiego" (WPK 488). Najciekawsza zaś jest może opinia Fika o powieści Mariana Czuchnowskiego Pieniądz (Kraków 1938; Bereza nie zauważa tego autora): „Język powieści jest prawdziwą rewelacją. Tak nie napisano jeszcze żadnej książki o wsi chłopskiej. O wsi szlacheckiej tak pisał Rej. Wysilano się jedynie na fonetyczny i ortograficzny żargon - i utożsamiano to z istotą chłopskości [...]. Czuchnowski odkrył twórcze prawa ducha mowy chłopskiej i uczynił z nich narzędzie nowej ekspresji artystycznej, bogacąc w ten sposób stylistykę polską o nowe tropy i figury, wydedukowane z odrębnej psychologii, co więcej - z odrębnej logiki chłopskiej" (WPK 199-200).

Oczywiście są też różnice: Fik nie rezygnował z mocnego pojęcia klasy społecznej (rezygnację tę zarzucał Brzozowskiemu), Bereza walkę klasową zamienił ostatecznie w starcie dwóch abstrakcyjnych bytów, języka pierwszego i języków wtórnych (jak wykładał w programowym eseju Ziemia pisarza z BR). Język pierwszy to inne imię chłopskiej genealogii kulturalnej, ale imię, w którym roztapia się sama ta genealogia. Niemniej, jak sądzę, źle rozumiemy Berezę, jeśli czynimy z niego apologetę czystego estetyzmu i wyznawcę hasła sztuki dla sztuki. Jest on raczej późnym zwolennikiem awangardowej i lewicowej idei mówiącej, że emancypacja społeczna jest czymś cennym z tego powodu, że wyzwala człowieka ku wolności, której najwyższa postać wyraża się w tworzeniu sztuki. Ostatecznie, skoro dzieło emancypacji nigdy się nie spełnia, choć trwa wiecznie, sztuka okazuje się rekompensatą udręk niesionych przez nowoczesność. W tym sensie - i chyba tylko w tym - anachronizm Berezy może stanowić dla niektórych z nas pewną pokusę ${ }^{42}$. 
5.

Czy nurt chłopski się skończył - i jak? Przywołajmy trzy tylko wypowiedzi. Według Andrzeja Mencwela był wyczerpany już w roku 1979. Wedle tej dobitnej diagnozy skończył się lingwistycznym eskapizmem („czystość przeciwieństw językowych"43) i antropologicznym mistycyzmem ("globalny, pozahistoryczny, mistycyzujący ogląd kultury ludowej"44), sprawiającymi w efekcie, że nurt chłopski to „literatura specyficznie inteligencka, w najlepszym razie inteligencji pochodzenia chłopskiego, tworzącej [sobie] moralne i kulturalne alibi" ${ }^{\prime 5}$. Jedna rzecz nie jest tylko jasna: Mencwel krytykuje de facto nie tyle samą literaturę, ile program Berezy, tak jakby zakładał, że na jedno wychodzi. To chyba nazbyt pochlebne dla Berezy... Ponadto zdaje się nie odróżniać pierwszego programu Berezy (ze Związów naturalnych) od drugiego (z Biegu rzeczy i Obrotów). Tu z kolei nie bez winy jest sam Bereza...

W tym samym 1979 roku Andrzej Zawada zastanawiał się nad tym, Czym jest ludowość wspótczesnej prozy? Na podstawie analiz literackich dowodził, że "chłopskość pojęta jako paradygmat kultury” już nie istnieje. Pisarze chłopscy nie tylko są równie wykorzenieni jak wszyscy inni, ale ponadto są wykorzenieni z własnej, chłopskiej kultury. Nie ze swojej winy, to raczej „[n]ormy [kultury chłopskiej] straciły moc regulującą, odpowiedzi straciły swą bezwzględną prawdziwość". Jeśli chłopskość coś jeszcze oznacza, to tylko „postawę permanentnej niezgody na przyjęcie «obcych» norm kulturowych" - problem polega jednak na tym, że wszystkie jawią się jako obce. Podobnego rozpadu, jak kultura chłopska, doznały bowiem także inne „tradycyjne formacje: mieszczańska, proletariacka, inteligencka; wiemy dobrze, jak trudno wskazać obecnie ich desygnaty". Pozostała plebejskość. Zawada okazuje się mimo to optymistą: coś się skończyło, ale zaczyna się coś innego. „Widać już wyraźnie kres zjawiska nazywanego nurtem chłopskim. Nie ma

oparcie historyczne w fakcie, że cechą „ludowości renesansowej była orientacja na przekształcenie, na zmianę, a nie reprodukcję, czy utrwalanie tradycji" oraz nie mogła być "redukowana do sztuki ludowej, sztuki stosowanej, folkloru, rzemiosła, czy też bezpośrednio wyrażających się interesów ludowych" (R. Sulima Ludowość a świadomość współczesna , "Regiony” 1978 nr 1, S. 18). Jest to ludowość nie oparta na różnicy kulturowej. Podział przebiegał za to gdzie indziej: „pomiędzy tendencjami humanizmu i reakcji przeciw humanizmowi (tamże, s. 20).

A. Mencwel Na progu współczesności, w: tegoż Spoiwa. Refleksje krytyczne, Warszawa 1983, S. 244 .

Tamże, s. 246. 
on jednak w sobie nic z końca jakiejś tendencji anachronicznej”. Przeciwnie, ,jest początkiem tendencji nowej, szerszej, zdolnej do głębszych analiz i uogólnień”. Nazywa ją Zawada, za Ziątkiem, „literaturą nowych doświadczeń społecznych" ${ }^{16}$. Niestety, dodajmy, nazwa ta raczej się nie przyjęła - co być może jest znaczące.

Wreszcie Wiesław Myśliwski, najwybitniejszy przedstawiciel nurtu chłopskiego - i bez wątpienia jeden z najwybitniejszych współczesnych pisarzy. W roku 2004 ogłosił on esej Kres kultury chtopskiej ${ }^{47}$. Stwierdzał, że inteligent polski niewiele o niej wie, że "aż do ostatnich swoich dni pozostawała na uboczu”. Chłopów „darzono albo współczuciem, albo obojętnością, albo się ich bano, albo ich eksploatowano, albo ich lekceważono, albo im schlebiano, nigdy ich tak naprawdę nie rozumiejąc”. Ludowość redukuje chłopskość do folkloru - pomysł inteligencki; „,udało się, niestety, w powszechnym użyciu zaszczepić termin «kultura ludowa» zamiast «kultura chłopska»". Ludowość, jak plastelina, poddaje się „koniunkturalizacji, ideologizacji, każdemu upartyjnieniu i każdemu upaństwieniu”, ale ma się dziś świetnie, podczas gdy „kultura chłopska na naszych oczach, chociaż poza naszą świadomością, umarła". Ludowość to "uprzemysłowiony folklor czy nawet postfolklor", chłopskość zaś opierała się na tym, że „chłop nie wiedział, jaki jest jego folklor, wiedział, jaki jest jego los". Z kultury chłopskiej wyłania się zatem „wielkie człowiecze uniwersum, a nie folklor". Zniewolony społecznie chłop w jednym był wolny - w języku. Wolny „od wszelkich kompendiów językowych, słowników, poradników i kanonów, zwłaszcza od tzw. poprawnej polszczyzny". Niestety, ,kultura chłopska przegrała starcie z napierającą cywilizacją”.

Ciekawe jest, że Myśliwski powiedział tu wiele z tego, co w roku 1973 wysłowił w trakcie dyskusji w „Nowym Wyrazie”. Z jedną różnicą: wtedy postęp cywilizacji uznawał za coś, co stymuluje zwrot w stronę chłopskich źródeł kultury ${ }^{48}$. Potem zmienił zdanie. Ponadto już wówczas aprobatywnie powoływał się na Berezę. Po latach, nazwisko autora Związków naturalnych okaże się jedynym nazwiskiem, jakie padnie w wykładzie na temat kresu kultury chłopskiej. Też, oczywiście, w kontekście niezwykle aprobatywnym - nie przez przypadek. Przytaczałem tak obszernie esej Myśliwskiego, żeby stało się jasne, że w zasadzie mówi on Berezą. W pełen urody sposób wykłada główne

\footnotetext{
46 A. Zawada Czym jest ludowość współczesnej prozy? "Tygodnik Kulturalny” 1979 nr 1, s. 4.

48 Zob. Temat wiejski, nurt chłopski czy kryterium wartości (fragmenty dyskusji), „Nowy Wyraz. Miesięcznik literacki młodych" $1973 \mathrm{nr}$ 7, s. 147.
} 
idee zarysowane w Zwiazkach naturalnych. Choć zapewne równie dobrze można by powiedzieć na odwrót: że to Bereza mówi Myśliwskim.

\section{6.}

Zakończymy czymś, co wolno uznać za rodzaj chłopskiej przypowieści. Otóż jest sad. W nim „jabłoń uginająca się od owoców w różnym stadium dojrzewania. Jest to jabłoń ze starego chłopskiego sadu, bujna, rozłożysta, nie przypominająca w niczym drzewnych kalek, które zmuszono do produkcji nylonowych jabłek”. I jest „nocny złodziej jabłek, który w ciemności ogałaca gałąz po gałęzi, ufając, że łup w całości okaże się smakowity, chociaż muszą się trafić owoce o smaku cierpkim lub wręcz niejadalnym". (ZN 152). Za pomocą tej przypowieści Bereza objaśniał Sklepienia niebieskie Józefa Ozgi-Michalskiego, książkę, którą cenił. Ale to teraz mniej ważne. Otóż w tej przypowieści złodziejem ogałacającym gałąź po gałęzi, mimo całego ryzyka, jest czytelnik. Bereza chciał być takim czytelnikiem - „nocnym złodziejem jabłek”. Choć do dziś nie bardzo wiadomo, co nakradł.

\section{Abstract}

\section{Andrzej Skrendo}

UNIVERSITY OF SZCZECIN

'The Nocturnal Apple Thief': Henryk Bereza and the Peasant Tradition in Polish Fiction

This article explores Henryk Bereza's literary criticism as well as fiction in the so-called peasant tradition. This movement blossomed in the 1970s, and Bereza was the most important critic to tackle this phenomenon. What was the peasant tradition? What debates did it give rise to? What does it signify today?

\section{Keywords}

literary criticism, contemporary prose, peasant tradition 